\title{
PENGUKURAN TINGKAH LAKU PADA MODEL NYERI NEUROPATIK PERIFER: TIKUS DENGAN CCI (CHRONIC CONSTRICTION INJURY)
}

\author{
BEHAVIORAL ASSESMENT OF THE PERIPHERAL NEUROPATHIC PAIN \\ MODEL: RAT WITH CCI (CHRONIC CONSTRICTION INJURY)
}

Hanik Badriyah Hidayati, * Paulus Sugianto, * Junaidi Khotib, ** Chrismawan Ardianto, ** Kuntoro, *** Mohammad Hasan Machfoed*

\section{ABSTRACT}

Neuropathic pain occurs in $20 \%$ of patients with chronic pain. This mainly due to the lack of effective treatment and the presence of drug's side effects. Animal models have been broadly utilized in validating the therapeutic target and the development of analgesic drugs. Chronic constriction injury (CCI) is a model of peripheral neuropathic pain characterized by allodynia and hyperalgesia. Chronic constriction injury model is produced by loose ligation of the sciatic nerve resulting in nerve damage, thus sensitizes and lowers pain threshold. The pain threshold test is performed by providing a pressure and thermal sensory stimulus that results in observable withdrawal behavior. This article discusses several methods in assessing pain-related behavior on the CCI neuropathic pain model.

Keywords: Behavioral, chronic constriction injury, mechanical, neuropathic pain

\begin{abstract}
ABSTRAK
Nyeri neuropatik terjadi pada seperlima pasien dengan nyeri kronik. Hal ini disebabkan karena terapi nyeri neuropatik masih kurang efektif dan adanya efek samping obat. Model hewan terbukti bermanfaat untuk validasi target dan perkembangan obat analgesik. Chronic constriction injury (CCI) merupakan model nyeri neuropatik perifer dengan karakteristik alodinia dan hiperalgesia. Model CCI dibuat dengan memberikan ligasi longgar pada saraf skiatik yang menyebabkan kerusakan saraf, sehingga terjadi sensitisasi dan ambang nyeri menurun. Tes ambang nyeri dilakukan dengan memberikan stimulus sensorik berupa tekanan dan panas yang akan menghasilkan tingkah laku withdrawal yang bisa diobservasi. Artikel ini membahas penilaian tingkah laku nyeri pada model nyeri neuropatik CCI.
\end{abstract}

Kata kunci: Chronic constriction injury, mekanik, nyeri neuropatik, tingkah laku

*Departemen Neurologi FK Universitas Airlangga/RSUD Dr. Soetomo, Surabaya; **Departemen Farmasi Klinik, Fakultas Farmasi Universitas Airlangga, Surabaya; ***Departemen Biostatika dan Kependudukan Universitas Airlangga, Surabaya. Korespondensi: hanikhidayati@yahoo.com.

\section{PENDAHULUAN}

Definisi nyeri menurut International Association for the Study of Pain (IASP) adalah pengalaman sensorik dan emosional yang tidak menyenangkan terkait dengan kerusakan jaringan, baik aktual maupun potensial, atau yang digambarkan dalam bentuk kerusakan tersebut. ${ }^{1-3}$ Adapun nyeri neuropatik disebabkan oleh berbagai macam jejas atau penyakit atau disfungsi saraf pada jalur somatosensorik, baik sentral maupun perifer. ${ }^{4-6}$

Gangguan sinyal saraf somatosensorik tersebut bisa diakibatkan oleh trauma, inflamasi, penyakit metabolik (misal: neuropati diabetik), infeksi (misal: neuralgia posherpetik), tumor, toksin atau akibat penyakit saraf primer. ${ }^{3,7-8}$ Berdasarkan durasinya, nyeri neuropatik termasuk nyeri kronik. Nyeri neuropatik juga tergolong dalam nyeri patologis, serta memiliki karakteristik yang khas, yaitu alodinia dan hiperalgesia. Alodinia adalah persepsi nyeri yang diakibatkan oleh stimulus yang seharusnya tidak menimbulkan nyeri, sedangkan hiperalgesia adalah peningkatan respons atas stimulus yang secara normal terasa nyeri. . $^{3-4,8}$

Intensitas nyeri yang terjadi pada nyeri neuropatik berkisar dari sedang, berat, sampai sangat berat. ${ }^{9-10}$ Hal ini mengakibatkan nyeri neuropatik memiliki dampak berupa gangguan pada banyak aspek kehidupan pasien seperti kesehatan, pekerjaan, hubungan sosial, hobi, tidur, mood maupun kognitif, bahkan kecelakaan lalu lintas pada daerah perkotaan yang padat penduduk. ${ }^{11-13}$

Dalam beberapa dekade terakhir model hewan tikus telah membantu meningkatkan pengetahuan mendasar mengenai mekanisme nyeri dan terapi farmakologi nyeri. ${ }^{14-15}$ Salah satu model nyeri neuropatik perifer yang bisa dibuat dari tikus 
adalah chronic constriction injury (CCI), ${ }^{10,16-17}$ yang menyebabkan gangguan pada transmisi sinyal nosiseptif. ${ }^{18}$

Studi jejas saraf perifer CCI akan membantu memahami nosiseptif dan peristiwa yang berkontribusi pada terjadinya status nyeri kronik neuropatik, termasuk menemukan obat nyeri neuropatik yang masih belum memuaskan. Artikel ini juga mengenalkan tentang pengukuran nyeri pada tikus CCI, yaitu dengan mengukur tingkah laku tikus yang jarang dibahas pada jurnal-jurnal yang ada.

\section{PEMBAHASAN}

Chronic constriction injury pertama kali dikenalkan oleh Bennett dan Xie pada tahun 1988 dan dimodifikasi oleh Sommer dkk (Gambar 1).,13,16

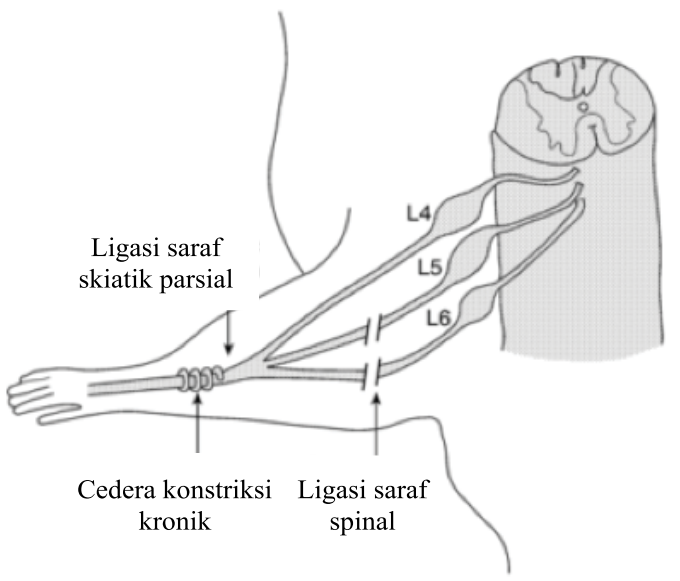

Gambar 1. Ilustrasi Pembuatan Model Chronic Constriction Injury, PSL (Partial Sciatic Nerve Ligation), dan L5/6 SNL (Spinal Nerve Ligation) pada Tikus/Mencit ${ }^{16}$

Karakteristik khas model CCI berupa alodinia dan hiperalgesia. ${ }^{5,18-19}$ Banyak temuan dalam dunia medis yang berkaitan dengan jalur nyeri neuropatik didapatkan dari penelitian dengan menggunakan model hewan CCI, antara lain peran kanal kalsium tipe $\mathrm{N}$ pada neuropati diabetik, efek antihiperalgesik obat diosmin melalui jalur sentral (reseptor dopaminergik $\mathrm{D}_{2}$ dan opioid) dan jalur perifer (penurunan sitokin antiinflamasi seperti TNF- $\alpha$, IL-1 $\beta$, dan IL-6), serta ditemukannya keterlibatan microRNA pada mekanisme terbentuknya nyeri neuropatik. ${ }^{4,19-20}$

Model CCI dibuat dengan cara membuat insisi longitudinal sepanjang $15 \mathrm{~mm}$ pada paha kanan level trokanter femoral tungkai posterior. Hal ini bertujuan mengekspos saraf skiatik setelah dilakukan diseksi gluteus dan biseps femoral. ${ }^{13-16}$ Model ini bisa dibuat dari hewan tikus dengan cara mengikatkan 4 buah ikatan menggunakan benang (4-0) chromic gut atau cat gut atau silk secara longgar pada saraf skiatik di pertengahan paha, yaitu $1 \mathrm{~mm}$ dari trifurkasio dan distal dari sciatic notch untuk menginduksi terjadinya sedikit iskemia saraf. ${ }^{5,9-10,13,16,20}$ Empat ikatan tersebut terbentang sepanjang $7 \mathrm{~mm}$ di sepanjang saraf skiatik dengan jarak antar ikatan $1 \mathrm{~mm} .{ }^{20}$ Dua ikatan paling luar diikatkan terlebih dahulu, dua ikatan sisanya diikatkan di tengah dua ikatan awal. Peneliti lain melakukan ikatan sebanyak 3 buah dengan jarak antar ikatan 1-1,5mm. ${ }^{9}$ Ikatan diberikan sampai tampak kaki belakang hewan mengalami twitching singkat. ${ }^{5,21}$

Selama prosedur pembedahan hewan dianestesi dengan salah satu dari bahan berikut: ketamine dan xylazine (Sigma-Aldrich) masing-masing $60 \mathrm{mg} /$ $\mathrm{kg}$ dan $8 \mathrm{mg} / \mathrm{kg}$; ketamine dan xylazine berturutan $50 \mathrm{mg} / \mathrm{kg}$ dan $7,5 \mathrm{mg} / \mathrm{kg}$ injeksi intra peritoneal (IP); tribromoethilene $25 \mathrm{mg} / \mathrm{kg}$ IP; chloralhydrate $4 \%$ $10 \mathrm{~mL} / \mathrm{kg}$ IP; sodium pentobarbital 50 atau $60 \mathrm{mg} /$ $\mathrm{kg}$ IP; pentobarbiton $50 \mathrm{mg} / \mathrm{kg}$ IP; isoflurane; dan sebagainya. ${ }^{5,913,16,20,22-23}$ Pascapembedahan luka dijahit dengan jahitan bedah nonabsorbable dan diberi salep antibiotik topikal. Semua pembedahan dilakukan oleh personil yang sama untuk meminimalisir perbedaan metode. ${ }^{16}$

Inflamasi akibat CCI akan menghasilkan perubahan baik neuropatologi maupun perubahan tingkah laku. Alodinia dan hiperalgesia tampak signifikan dalam 3-8 hari pascatindakan dan bisa berlangsung dalam jangka lama. ${ }^{5,9,19}$

\section{PENILAIAN TINGKAH LAKU PADA CCI}

Penilaian tingkah laku nyeri pada hewan coba seperti model nyeri neuropatik CCI bisa dinilai dari tingkah laku nyeri, baik yang terjadi secara spontan maupun secara induksi. ${ }^{13}$ Tes hiperalgesia mekanik dan termal berguna untuk mengukur toleransi antinosiseptik. Respons tingkah laku nyeri yang terjadi dapat bermacam-macam, misalnya: menghindar, menjilat, menyentak, bergoyang, 
menggigit, melompat, meregangkan abdomen, menarik diri, berlari, melindungi telapak kaki atau merubah postur. ${ }^{10,24-26}$

\section{Tingkah Laku Nyeri Spontan}

Tikus diletakkan dalam kandang berukuran $100 \mathrm{~cm} \times 50 \mathrm{~cm} \times 50 \mathrm{~cm}$ selama 5 menit untuk aklimatisasi. Masing-masing tikus eksperimen maupun kontrol diamati selama 30 menit. Pengamat mengidentifikasi masing-masing komponen tingkah laku dan merekamnya dengan menggunakan software komputer sebagai contoh Comporta ${ }^{(\mathrm{R})}$ yang didesain oleh Prof. Marcus Vale (Federal University of Ceara, Brazil). ${ }^{13}$

Pengamatan pertama dilakukan sebelum pembedahan (baseline), kemudian pada hari ke-5 dan ke-15 pascapembedahan. Dihitung rerata delta tingkah laku dari nilai baseline (dalam hitungan detik). Beberapa tingkah laku nyeri spontan yang bisa diamati antara lain mencakar dan menggigit. Dicatat waktu yang diperlukan untuk melukai kulit dengan gerakan mencakar dan menggigit. Mencakar adalah waktu yang diperlukan oleh tikus untuk mengangkat kaki belakang kiri atau kanan dan menggerakan cakarnya secara cepat untuk mencakar bagian tubuhnya, sedangkan respons menggigit adalah waktu yang diperlukan oleh tikus untuk menusuk bagian kulit kiri maupun kanan dengan mulut dan gigi. ${ }^{13}$

\section{Tingkah Laku Nyeri Induksi (Uji Nyeri Multimodal)}

Nyeri neuropatik bisa dinilai dengan uji nyeri multimodal yang meliputi hiperalgesia mekanik, hiperalgesia termal, alodinia mekanik, alodinia dingin, dan pain aversiveness (place escapelavoidance paradigm). Nilai dasar (baseline) diambil dari pre dan pasca-CCI..$^{19,27}$

\section{Hiperalgesia Mekanik}

Pemeriksaan ini merupakan stimulasi mekanik untuk menilai tingkah laku nosiseptif pada hewan coba. ${ }^{28}$ Sebelum dilakukan pemeriksaan, tikus dibiarkan beradaptasi dengan lingkungan selama 15 menit $^{20,28}$ atau 2 hari. ${ }^{29}$ Tikus diletakkan di sebuah kandang plastik berukuran $13 \mathrm{~cm} \times 21 \mathrm{~cm} \times 16 \mathrm{~cm}$ yang bagian bawahnya berupa kawat. ${ }^{20,28}$

Hiperalgesia mekanik dites dengan memberikan tekanan mekanik pada kaki model. ${ }^{28}$ Stimulus mekanik didapatkan dari alat von Frey ${ }^{30}$ yang terdiri dari beberapa buah filamen dalam ukuran gram. Filamen yang pernah digunakan adalah berukuran $0,6-26 \mathrm{~g},{ }^{28}$ atau 0,$40 ; 0,60 ; 1,40 ; 2,0 ; 4,0 ; 6,0 ; 8,0 ; 10,0$; dan $15,0 \mathrm{~g} .{ }^{31}$ Penelitian lain menggunakan filamen dengan ukuran $2,4,6,8,10,15,26$, dan $60 \mathrm{~g}$ dengan dimulai dari filamen berukuran $2,0 \mathrm{~g} .{ }^{16}$

Hewan coba dipegang oleh peneliti secara hati-hati sedemikian rupa sehingga meminimalisir induksi stres yang mungkin bisa terjadi. Masingmasing filamen von Frey diaplikasikan melalui dasar kandang pada permukaan plantar masing-masing kaki belakang secara perpendikular selama 5 detik dengan interval 15 detik, ${ }^{20,28}$ atau 6-8 detik dengan interval 30 detik, $^{28,31}$ atau selama 3 detik dengan interval 3 detik selama 3 kali. $^{16}$

Respons positif adalah saat tikus mengalami withdrawal tajam pada kaki belakang. ${ }^{20,28}$ Ambang withdrawal kaki terhadap stimulus mekanik digunakan sebagai indikator terhadap sensitifitas mekanik terhadap telapak kaki yang terkena stimulus. ${ }^{27}$ Ambang batas mekanik diukur dengan menggunakan metode "up-down". ${ }^{31-32}$ Saat terjadi respons positif terhadap stimulus, diaplikasikan filamen von Frey yang lebih kecil. Sebaliknya saat terjadi respons negatif, digunakan filamen yang lebih besar. ${ }^{31-16}$

Nilai cut off yang dipakai adalah $16 \mathrm{~g}^{10,20}$ dengan pemeriksaan sebanyak 10 kali. Jika ada withdrawal 5x dari 10 kali uji maka dinyatakan sebagai $50 \%$ ambang withdrawal. ${ }^{28,31}$ Para peneliti lainnya mengaplikasikan filamen von Frey sebanyak 3 kali. ${ }^{16}$ Hasil pemeriksaan dinyatakan sebagai PWT (paw withdrawal treshold).

Waktu pelaksanaan pemeriksaan dengan menggunakan von Frey ini berbeda-beda, ada yang melakukan pemeriksaan pada hari ke-3,7, dan 14 pascaoperasi, ada yang pada hari ke-0,2,7, dan 14 pascaoperasi, atau pada hari ke-1,3,5,7, dan 14 pascaoperasi, ada yang pada hari ke- $8,17,24$, dan 31 , serta ada yang pada hari ke-0,12,26,28, dan 35 pascaoperasi. ${ }^{10,16,20,32}$ Nilai baseline didapatkan dengan melakukan pemeriksaan von Frey sebelum pemberian terapi atau pembedahan. ${ }^{28,31}$ Sebuah penelitian melaksanakan pemeriksaan dengan 
menggunakan von Frey ini antara jam 9 pagi sampai jam 2 siang. ${ }^{31}$ Penelitian lain melakukan penilaian tingkah laku antara jam 10.00 hingga 14.00. ${ }^{16}$

\section{Hiperalgesia Termal}

Nyeri akan berpengaruh pada tingkah laku. ${ }^{33}$ Pada pemeriksaan hiperalgesia termal, panas diberikan pada telapak kaki untuk mengamati respons gerakan mencit. Respons atau sensitivitas nosiseptif terhadap stimulus termal akan diekspresikan sebagai PWL (paw withdrawal latency) dalam detik untuk memeriksa latensi. ${ }^{16}$ Sebelum dilakukan pemeriksaan, tikus dibiarkan beradaptasi dengan lingkungan (aklimatisasi) selama 15 menit. ${ }^{20} \mathrm{Ada}$ dua macam hiperalgesia termal, yaitu hiperalgesia panas dan hiperalgesia dingin.

Pada pemeriksaan hiperalgesia termal, hewan diletakkan pada kandang plastik dengan dasar kaca, kemudian panas diberikan pada kedua permukaan plantar kaki tikus. Beberapa sumber panas yang bisa digunakan antara lain simulator panas (BME-410 Peking Union Medical College Institue of Biomedical Engineering) atau hot plate.,20 Alat Cold/Hot Plate bisa menggunakan Cold/Hot Plate Analgesia Meter (No. 05044 Columbus Instruments, USA) atau algesimeter Ugo Basile (Comerio, Italy). 5,32 Kelebihan penggunaan sumber panas dengan focal radiant adalah panas bisa diberikan secara selektif pada satu kaki pada satu waktu. ${ }^{20}$

Durasi simulasi panas adalah 20 detik. Tes diulang sebanyak tiga kali dengan interval waktu 10 menit atau minimal 5 menit. ${ }^{20,32}$ Respons positif adalah saat terjadi withdrawal tajam kaki tikus. Nilai cut off adalah 20 detik. Nilai rerata 3 pengukuran dicatat sebagai PWL. ${ }^{20}$

Pada paw immersion test, air dipanaskan pada suhu $46^{\circ} \mathrm{C}$ (Ministat MHUB11, Bioblock Scientific, 67400 Illkirch, France). Latensi diukur dalam hitungan detik. Pada kasus tidak adanya respons tikus, paw immersion diberi waktu maksimum (cut off time) selama 15 detik. Cut off time ini diberlakukan untuk menghindari kerusakan jaringan. ${ }^{29}$

Hiperalgesia dingin dapat diukur dengan menggunakan cold plate. Hewan ditempatkan pada cold plate yang dipertahankan suhunya pada $5^{\circ} \mathrm{C}$. Waktu sejak hewan diletakkan sampai kaki belakang hewan terangkat dihitung dan dicatat. ${ }^{5}$

\section{Alodinia Mekanik}

Pemeriksaan alodinia untuk melihat tingkah laku nyeri neuropatik ini dilakukan dengan pemberian stimulus mekanik pada kaki belakang. Sensitivitas mekanik pada kaki belakang diukur dengan menentukan ambang withdrawal pada filamen von Frey. Dilakukan perekaman ambang batas tekanan (dalam gram) saat terjadi tarikan kaki. ${ }^{5}$

Disiapkan satu plastik set filamen von Frey terkalibrasi dengan ukuran semakin meningkat. Ukuran filamen von Frey yang dipakai berbeda sesuai dengan berat hewan. Untuk mencit berkisar antara 0,07-2g, sedangkan untuk tikus berkisar antara $1-100 \mathrm{~g} .{ }^{34}$ Alat yang digunakan bisa menggunakan salah satu dari the 2392 Electronic von Frey Anesthesiometer (IITC Life Science, USA); von Frey otomatis (Dynamic Plantar Anesthesiometer Cat. No. 37400, Ugo Basile Italy); von Frey ('TouchTest', North Coast Medical, Inc., San Jose, CA; von Frey filaments (Stoelting, Wood Dale, IL) atau menggunakan BME-404 Mechanical Analgesia Tester (CAMS-Chinese Academy of Medical Sciences, Beijing, China). 5, $18,22,35-36$

Tikus ditempatkan di dalam kandang kotak plexiglass berukuran $30 \mathrm{~cm} \times 30 \mathrm{~cm} \times 30 \mathrm{~cm}$ dengan dasar lantai berbentuk jala, lalu dibiarkan beradaptasi dengan lingkungan selama 30 menit sebelum tes. ${ }^{5,16}$ Dapat digunakan filamen von Frey ukuran $2,4,6,8,10,15,26$ dan $60 \mathrm{~g}^{5,16}$ yang diaplikasikan di jaringan lunak midplantar telapak kaki untuk menentukan withdrawal treshold.

Filamen pertama yang dipakai adalah yang sesuai dengan tekanan $2 \mathrm{gr}$. Tiap filamen diaplikasikan selama 3 detik, sebanyak 2 atau 3 kali, dengan interval minimal 3 detik antar pengaplikasian. Jika respons negatif (tidak ada respons), maka diganti dengan tekanan yang lebih besar. Namun jika respons positif (ada respons), digunakan filamen yang lebih besar. Jika tampak dua respons positif (paw treshold), maka skor yang didapat dianggap sebagai respons ambang. Jika hewan tidak merespons dengan 60gram, maka skor 60gram tersebut dianggap sebagai respons treshold. Kemudian dihitung nilai reratanya. ${ }^{5,16}$

Saat kaki belakang mengalami penarikan, stimulus mekanik secara otomatis akan ditarik. 
Tekanan yang direkam adalah yang terdekat dengan 0,1 g. ${ }^{5}$ Respons nosiseptif untuk sensitivitas mekanik didapatkan dari nilai rerata dan disebut sebagai PWT (paw withdrawal threshold) atau MWT (mechanical withdrawal threshold) atau PWMT (paw withdrawal mechanical threshold) yang dinyatakan dalam gram. ${ }^{35}$ Sebuah penelitian memeriksa PWMT pada hari sebelum operasi, 4 hari pascaoperasi, dan 2 jam setelah injeksi obat (obat inhibitor). ${ }^{35}$

Adapun cara pemeriksaan dengan alat $B M E$ 404 Mechanical Analgesia Tester adalah dengan menekankan probe pada permukaan plantar lateral. Pemeriksaan dilakukan selama 5 menit sebanyak 5 kali dengan minimal 5 menit interval waktu antar pengujian. Respons dinyatakan positif saat didapatkan withdrawal, selanjutnya dihitung nilai rerata dan dilakukan analisis statistik. ${ }^{35}$

\section{Alodinia Termal}

Alodinia dingin bisa diuji menggunakan cold plate bersuhu $-4^{\circ} \mathrm{C}$ atau tes aseton. ${ }^{37}$ Penelitian lain menyebutkan bahwa teknik tes aseton tidak cocok mewakili alodinia dingin, namun lebih cocok dimasukkan sebagai respons withdrawal noksius secara umum. Pada tes aseton, aseton bisa diberikan pada telapak kaki dengan cara pemberian berupa tetesan atau semprotan dengan skala kecil, yang kemudian evaporasinya akan menyebabkan terjadinya efek pendinginan yang menyebabkan rasa tidak enak. Pemberian aseton dianggap sebagai stimulus dingin yang tidak membahayakan. Penggunaan teknik ini akan menyebabkan penurunan temperatur kulit sekitar $8-12^{\circ} \mathrm{C}$. Kelebihan yang tes aseton adalah kemampuan tes ini untuk menstimulasi tingkah laku aversive secara unilateral. ${ }^{15}$

\section{KESIMPULAN}

Chronic constriction injury merupakan salah satu model nyeri neuropatik perifer. Hasil uji efek analgesik suatu obat yang digambarkan dari penilaian tingkah laku nyeri terkadang masih terbilang kontroversial. Hal ini salah satunya disebabkan oleh adanya perbedaan tempat dilakukannya stimulasi nyeri (ekor atau telapak kaki tikus), perbedaan tipe stimulus (imersi atau semprot dingin) dan perbedaan cara metode akuisisi data (latensi withdrawal atau frekuensi respons). Secara umum, studi jejas saraf perifer dengan model CCI akan membantu dalam memahami nosiseptif dan mekanisme yang berkontribusi pada terjadinya status nyeri kronik.

\section{DAFTAR PUSTAKA}

1. Kapur BM, Lala PK, Shaw JL V. Pharmacogenetics of chronic pain management. Clin Biochem. 2014;47(13-14):1169-87.

2. Salvat E, Yalcin I, Barrot M. Review antidepressants and gabapentinoids in neuropathic pain: mechanistic insights. Neuroscience. 2016;338:183-206.

3. Mihai C, Iulian V, Harsovescu T. When pain is useful ?-a neuroscience approach. Procedia-Soc Behav Sci. 2014;127:671-5.

4. Khan S, Kaur H, Sharma G. Role of various mechanisms and pathways in diabetic neuropathy: an overview. Int $\mathrm{J}$ Pharmaceut Sci Letters. 2015;5(1):495-500.

5. Pilat D, Rojewska E, Jurga AM, Piotrowska A, Makuch W, Przewlocka B, dkk. IL-1 receptor antagonist improves morphibe and buprenorphine efficacy in a rat neuropathic pain model. Eur J Pharmacol. 2015;764:240-8.

6. Khan N, Smith M. Neurotrophins and neuropathic pain: role in pathobiology. Molecules. 2015;20(6): 10657-88.

7. Gereau RW, Sluka KA, Maixner W, Savage SR, Price TJ, Murinson BB, dkk. A pain research agenda for the 21st century. J Pain. 2014;15(12):1203-14.

8. Tiwari V, Guan Y, Raja SN. Modulating the delicate glial-neuronal interactions in neuropathic pain: promises and potential caveats. Neurosci Biobehav Rev. 2014;45:19-27.

9. Khan J, Ramadan K, Korczeniewska O, Moin M, Benoliel R, Eliav E, dkk. Interleukin-10 levels in rat models of nerve damage and neuropathic pain. Neurosci Lett. 2015;10;592:99-106.

10. Dias QM, Rossaneis AC, Fais RS, Prado WA. An improved experimental model for peripheral neuropathy in rats. Brazilian $\mathrm{J}$ Med Biol Res. 2013;46(3):1-4.

11. Yalcin I, Barthas F, Barrot M. Emotional consequences of neuropathic pain: insight from preclinical studies. Neurosci Biobehav Rev. 2014;47:1-39.

12. Qu L, Ma C. Animal models of pain after peripheral nerve injury. Dalam: Ma C, Zhang JM, editor. Animal models of pain. Edisi pertama. New York: Humana Press; 2011. h. 69-80.

13. Camara CC, Araujo CV, Kelma K, de Sousa KK, Brito GA, Vale ML, dkk. Gabapentin attenuates neuropathic pain and improves nerve myelination after chronic sciatic constriction in rats. Neurosci Letters. 2015;607:52-8. 
14. Castel D, Sabbag I, Brenner O, Meilin S. Peripheral neuritis trauma in pigs: a neuropathic pain model. J Pain. 2016;17(1):36-49.

15. Yin $\mathrm{K}$, Zimmermann $\mathrm{K}$, Vetter I, Lewis RJ. Therapeutic opportunities for targeting cold pain pathways. Biochem Pharmacol. 2015;93(2):125-40.

16. Konopka K. Predictivity of pain models. Ger Assoc Appl Hum Pharmacol (AGAH)-Annu Meet. 2014. h. $1-27$.

17. Jarahi M, Sheibani V, Safakhah HA, Torkmandi H. Effects of progesterone on neuropathic pain responses in an experimental animal model for peripheral neuropathy in the rat: a behavioral and electrophysiological study. IBRO. 2014;256:403-11.

18. Belozertseva I, Nagel J, Valastro B, Franke L, Danysz W. Optical isomers of phenibut inhibit $[\mathrm{H}$ 3]-Gabapentin binding in vitro and show activity in animal models of chronic pain. Pharmacol Reports. 2016;68(3):550-4.

19. Carballo-villalobos AI, Gonzalez-trujano ME, Alvarado-vasquez N, Lopez-munoz FJ. Central and peripheral anti-hyperalgesic effects of diosmin in a neuropathic pain model in rats. Biomed Pharmacother. 2018;97:310-20.

20. Andersen HH, Duroux M, Gazerani P. MicroRNAs as modulators and biomarkers of inflammatory and neuropathic pain conditions. Neurobiol Dis. 2014;71:159-68.

21. Delfini M, Mantilleri A, Gaillard S, Hao J, Reynders A, Malapert P, dkk. TAFA4, a chemokine-like protein, modulates injury-induced mechanical and chemical pain hypersensitivity in mice. Cell Rep. 2013;5(2):378-88.

22. Yogeeswari P, Patel SK, Reddy IV, Semwal A, Sharma M, Gangadhar M, dkk. GABA derivatives for the treatment of epilepsy and neuropathic pain: a synthetic integration of GABA in 1, 2, 4Triazolo-2H-one nucleus. Biomed Aging Pathol. 2012;2(2):31-40.

23. Barrot M. Tests and models of nociception and pain in rodents. Neurosci. 2012;211:39-50.

24. Watson C. Increasing endogenous levels of GABA in rat insula decreases various aspects of pain found in a rodent model of chronic neuropathic pain. J Pain. 2014;15(4):S51.

25. Watson $\mathrm{C}$. Increasing endogenous levels of GABA in rat insula decreases various aspects of pain found in a rodent model of chronic neuropathic pain. J Pain. 2014;15(4):S51.

26. Noda K, Akita H, Ogata M, Saji M. Paclitaxel-induced hyperalgesia modulates negative affective component of pain and NR1 receptor expression in the frontal cortex in rats. Neurosci Res. 2014;80(1):32-7.
27. Li R, Shen L, Yu X, Ma C, Huang Y. Vitamin C enhances the analgesic effect of gabapentin on rats with neuropathic pain. Life Sci. 2016;157:25-31.

28. Viguier F, Michot B, Kayser V, Bernard J, Vela J, Hamon M, dkk. GABA, but not opioids, mediates the anti-hyperalgesic effects of 5-HT 7 receptor activation in rats suffering from neuropathic pain. Neuropharmacol. 2012;63(6):1093-106.

29. Takeda M, Takahashi M, Kitagawa J, Kanazawa T, Nasu M. Brain-derived neurotrophic factor enhances the excitability of small-diameter trigeminal ganglion neurons projecting to the trigeminal nucleus interpolaris/caudalis transition zone following masseter muscle inflammation. Mol Pain. 2013;9(1):49.

30. Zhou TT, Wu JR, Chen ZY, Liu ZX, Miao B. Effects of dexmedetomidine on P2X4Rs, p38-MAPK and BDNF in spinal microglia in rats with spared nerve injury. Brain Res. 2014;1568:21-30.

31. Leo M, Schmitt L, Erkel M, Melnikova M, Thomale J, Hagenacker T, dkk. Cisplatin-induced neuropathic pain is mediated by upregulation of $\mathrm{N}$-type voltagegated calcium channels in dorsal root ganglion neurons. Exp Neurol. 2017;288:62-74.

32. Lee J. How to erase memory traces of pain and fear. Trends Neurosci. 2013;36(6):343-52.

33. Hulse RP, Beazley-Long N, Hua J, Kennedy H, Prager J, Bevan H, dkk. Neurobiology of disease regulation of alternative VEGF-A mRNA splicing is a therapeutic target for analgesia. Neurobiol Dis. 2014;71:245-59.

34. Tu W, Cheng R, Cheng B, Lu J, Cao F, Lin H, dkk. Analgesic effect of electroacupuncture on chronic neuropathic pain mediated by $\mathrm{P} 2 \mathrm{X} 3$ receptors in rat dorsal root ganglion neurons. Neurochem Int. 2012;60(4):379-86.

35. Chen W, McRoberts JA, Marvizon JCG. $\mu$-Opioid receptor inhibition of substance $\mathrm{P}$ release from primary afferents disappears in neuropathic pain but not inflammatory pain. Neurosci. 2014;267:67-82.

36. Khan H, Eto B, De Feo V, Gilani AU. Evidence based alternative medicines in pain management. EvidenceBased Complement Altern Med. 2015;2015:1-2.

37. Zhu S, Wang C, Han Y, Song C, Hu X, Liu Y. Sigma-1 receptor antagonist BD1047 reduces mechanical allodynia in a rat model of bone cancer pain through the inhibition of spinal NR1 phosphorylation and microglia activation. Mediators Inflamm. 2015;2015:1063-73.

38. Minett MS, Falk S, Santana-Varela S, Bogdanov YD, Nassar MA, dkk. Pain without nociceptors? Nav1.7-Independent Pain Mechanisms. Cell Reports. 2014;6(2):301-12. 